
МЕТОДОЛОГІЧНІ ПІДХОДИ ТА ПРИНЦИПИ ФОРМУВАННЯ ПРОФЕСІЙНОЇ
КОМПЕТЕНТНОСТІ МАЙБУТНІХ ТРАКТОРИСТІВ-МАШИНІСТІВ

\title{
METHODOLOGICAL APPROACHES AND PRINCIPLES OF FORMATION OF PROFESSIONAL COMPETENCE OF FUTURE TRACTORS-DRIVERS
}

\begin{abstract}
Стаття присвячена одній з актуальних проблем підготовки майбутніх трактористів-машиністів - формуванню їхньої профресійної компетентності. Мета статті - розглянути методологічні підходи й принципи щодо формування профресійної компетентності майбутніх трактористів-машиністів. Необхідним і важливим для формування професійної компетентності майбутніх трактористів-машиністів є розроблення проєкту реалізації компетентнісної концепції та його унаочнення у вигляді структурної моделі, яка відбиває систему формування профресійної компетентності майбутніх трактористів-машиністів у перебігу профресійної підготовки. Визначені методологічні підходи (системний, компетентнісний, діяльнісний та особистісно-розвивальний) дають змогу схарактеризувати соормування профе сійної компетентності майбутніх трактористів-машиністів як керований процес у межах закладу освіти. Ураховуючи складність системи методологічних підходів, можна стверджувати, що кожен із них може бути реалізованим повною мірою тільки в їх сукупності.
\end{abstract}

Зазначені принципи (об'єктивності; всебічності; єдності історичного й логічного; системності; партнерства й співробітництва; розвивального й виховального навчання; профессійної мобільності; фуундаментальності освіти модульності; професійної спрямованості; інсрорматизації (комп'ютеризації) навчання; безперервності; прямого й зворотного зв'язку з виробництвом; створення інфоормаційно-освітнього середовища; моделювання технічної діяльності ; економічної доцільності) спрямовані на реалізацію концептуальних ідей цілеспрямованого орормування просресійної компетентності майбутніх трактористів-машиністів сільськогосподарського виробництва. Усі розглянуті методологічні підходи й принципи в комплексі передбачають аналіз педагогічних проблем, виявлення та зіставлення їх значущості, пропонують свої шляхи й методи розв'язання цих проблем.
Ключові слова: фрормування професійної компетентності, майбутні трактористи-машиністи, методичні підходи, принципи.

The article is devoted to one of the urgent problems of training future tractor drivers - the formation of their professional competence. The purpose of the article is to consider methodological approaches and principles for the formation of professional competence of future tractor drivers. Necessary and important for the formation of professional competence of future tractor drivers is the development of a project for the implementation of the concept of competence and its presentation in the form of a structural model that reflects the system of professional competence of future tractor drivers during training. Certain methodological approaches (systemic, competence, activity and personal development) allow to characterize the formation of professional competence of future tractor drivers as a managed process within the educational institution. Given the complexity of the system of methodological approaches, it can be argued that each of them can be fully implemented only in their entirety.

These principles (objectivity; comprehensiveness; unity of historical and logical; systemic; partnership and cooperation; developmental and educational training; professional mobility; fundamental education; modularity; professional orientation; informatization (computerization) of learning; continuity; direct and inverse communication. with the production; creation of information and educational environment; modeling of technical activities; economic feasibility) aimed at implementing the conceptual ideas of purposeful formation of professional competence of future tractor drivers of agricultural production. All considered methodological approaches and principles in the complex provide analysis of pedagogical problems, identification and comparison of their significance, offer their ways and methods of solving these problems.

Key words: formation of professional competence, future tractor drivers, methodical approaches, principles.
Постановка проблеми в загальному вигляді. Реалізація завдань розвитку професійно-технічної освіти, що визначені положеннями Закону України «Про професійно-технічну освіту», Національної доктрини розвитку освіти України у XXI столітті, Національної стратегії розвитку освіти в Україні на період до 2021 р., консолідує зусилля педагогічної громадськості в стратегічному напрямі: створити належні умови для забезпечення країни якісним трудовим потенціалом шляхом задоволення потреб особистості й держави в освітніх послугах із підготовки робітників з орієнтиром на фрормування творчої, духовно багатої особистості. Це вкрай важливе завдання: нині пріоритети роботодавців схиляються до випускника професійно-технічного навчального закладу, зокрема тракториста-машиніста сільськогосподарського виробництва, який вже з перших днів роботи за фахом здатний компетентно, ефективно й відповідально виконувати складні виробничі завдання, готового до постійного профресійного зростання, соціальної та профресійної мобільності. 
Провідний у сучасній професійній освіті компетентнісний підхід до навчання та виховання молоді пов'язаний насамперед з ідеєю системної підготовки індивіда не лише як профресіонала, але і як особистості, здатної до саморозвитку, самовиховання, самоосвіти. Важливим нині $€$ не тільки обсяг знань випускника профресійно-технічного навчального закладу, а й уміння ними оперувати, бути готовим змінюватися та пристосовуватися до нових потреб ринку праці, оперувати й управляти інформацією, активно діяти, швидко приймати рішення, навчатися впродовж життя.

Аналіз останніх досліджень і публікацій. Проблема застосування компетентнісного підходу до підготовки фрахівців, кваліфікованих робітників привертала увагу багатьох науковців. Фундаментальне значення для педагогічної науки в розробці проблем формування профресійної компетентності мають роботи С. Амеліної, В. Байденка, Н. Бібік, С. Гончаренка, І. Зязюна, В. Кременя, Н. Ничкало, В. Лугового, О. Пометун, В. Радкевич та інших. Наукові аспекти професійної підготовки кваліфрікованих робітників, зокрема й для сільськогосподарського виробництва, порушувалися М. Артюшиною, М. Вайнтраубом, Г. Васяновичем, Т. Герлянд, Д. Гуменним, Р. Гуревичем, Б. Кошуком, П. Лузаном, Г. Лук'яненко, В. Маньком, В. Орловим, Л. Петренко, Г. Романовою, В. Свистун, В. Ягуповим та іншими. Однак поза увагою вчених залишилися вкрай важливі змістово-технологічні аспекти фрормування професійної компетентності майбутніх трактористів-машиністів сільськогосподарського виробництва. Визначено, що професійну компетентність слід розглядати як фрактор соціальної конкурентоспроможності випускника, оскільки вона $€$ результатом якісної освіти, опанування професійними здатностями, досягнення певної кваліфрікації та дозволяє за необхідності перемінити спеціальність.

Виділення не вирішених раніше частин загальної проблеми. Проте в педагогічній науці не досить розробленими лишаються положення про цілі, зміст, технології, методи, форми й принципи компетентнісно орієнтованої підготовки майбутніх трактористів-машиністів сільськогосподарського виробництва.

Мета статті - розглянути методологічні підходи й принципи щодо фрормування профресійної компетентності майбутніх трактористів-машиністів.

Виклад основного матеріалу. Необхідним і важливим для фрормування профресійної компетентності майбутніх трактористів-машиністів $€$ розроблення проєкту реалізації компетентнісної концепції та його унаочнення у вигляді структурної моделі, яка відбиває систему формування професійної компетентності майбутніх трактористівмашиністів у перебігу профресійної підготовки й складається із чотирьох взаємопов'язаних блоків: методологічно-цільового, суб'єктного, змістовотехнологічного, діагностико-корегувального.

Методологічно-цільовий блок моделі містить: соціальне замовлення; мету; завдання; методологічні підходи й принципи щодо формування профресійної компетентності майбутніх трактористівмашиністів сільськогосподарського виробництва. Зупинимося на цих складниках детальніше.

Важливо відзначити, що засобом реалізації соціального замовлення виступає освітній стандарт у системі вимог до компетентностей, які має демонструвати випускник.

Метою процесу профресійного навчання в такій моделі є формування профресійної компетентності майбутнього тракториста-машиніста як інтегративної риси особистості, що містить фрормування та розвиток професійних знань, умінь і навичок, професійно значущих рис особистості, ціннісних орієнтацій і мотивації до майбутньої професійної діяльності. Підкреслимо, що мета досліджуваного процесу спричиняється соціальним замовленням на фрахівців-аграрників як професійно компетентних, духовно розвинутих особистостей.

Завдання формування професійної компетентності синтезують у собі комплекс мотивованих знань, умінь, навичок, необхідних для здійснення професійної діяльності; розвиток мотиваційних, самоосвітніх здібностей та якостей майбутніх трактористів-машиністів; набуття досвіду продуктивної професійно-комунікаційної взаємодії; сталий розвиток мотивації учнів до самоосвітньої діяльності.

Методологія формування професійної компетентності майбутніх трактористів-машиністів спрямовує процес на дотримання вимог і положень основних методологічних підходів і принципів.

У дослідженні методологічні підходи розуміються як вихідні, ключові фрундаментальні педагогічні положення (теорії, концепції, гіпотези), які мають загальнонауковий зміст [2, с. 499]. Діалектична єдність підходів визначає методологію нашого дослідження «<...> як систему принципів і способів побудови теоретичної та практичної діяльності, < ..>> фрорми й способи науково-дослідної діяльності» [5, с. 365].

За результатами аналізу наявних наукових праць, детального вивчення педагогічної практики підготовки кваліфікованих робітниківаграрників визначено методологію наукового пошуку як єдність системного, компетентнісного, діяльнісного й особистісно-розвивального підходів, зокрема:

- системний підхід, за яким освітній процес закладу професійної (професійно-технічної) освіти має розглядатися як педагогічна система, що фрункціонує шляхом взаємозв'язків її складників, визначає, що модернізувати, вивести усталений освітній процес із рівноваги можна тільки 
шляхом удосконалення всіх наявних елементів системи. Системний підхід забезпечує вивчення такого френомена як складного, багаторівневого утворення особистості, яке за відповідних умов розвивається та має певну структуру. Застосування системного підходу передбачає поєднання методичних напрямів, технологій, методів, прийомів, фрорм і засобів фрормування професійної компетентності майбутніх трактористів-машиністів;

- компетентнісний підхід у професійній освіті спрямований на досягнення основної мети - підготовки кваліфікованого робітника, фрахівця відповідного рівня та профрілю, конкурентоспроможного на ринку праці, який вільно володіє професією чи спеціальністю, може творчо виконувати виробничі завдання, орієнтований у суміжних сорерах діяльності, спроможний працювати на рівні світових стандартів, готовий до постійного професійного вдосконалення, $є$ соціально й професійно мобільним. Компетентнісний підхід передбачає фрормування та розвиток здатностей їх практичного застосування в майбутній виробничій діяльності й дозволяє зорієнтувати педагогічний процес на виконання соціального замовлення - підготувати фрахівця, який за своїми професійними й особистісними якостями відповідає вимогам освітнього стандарту. Компетентнісний підхід орієнтується на професійну компетентність як якість особистості майбутнього фрахівця, що характеризує рівень його інтеграції в середовище прооресійної діяльності, як і в різні соціальні середовища, входження в які виявляє необхідність виконувати різні соціальні ролі [4, с. 11].;

- діяльнісний підхід до фрормування професійної компетентності забезпечує спрямованість освітнього процесу на розвиток ключових компетентностей особистості майбутнього кваліфрікованого робітника, опанування учнем уміннями самоосвітньої діяльності й командної роботи, успішну інтеграцію в соціум і профресійну самореалізацію випускника закладу професійної (профресійно-технічної) освіти, застосування теоретичних знань на практиці й передбачає системно-послідовне включення вихованців у різновиди навчальної та навчально-просресійної діяльності;

- особистісно-розвивальний підхід дає можливість розвинути природні якості учнів, їхні пізнавальні здібності, професійні інтереси, вподобання, нахили, підготувати учнівську молодь до свідомої громадянської діяльності в різних сорерах життя шляхом створення умов, за яких суб'єкти освітнього процесу закладу професійної (професійно-технічної) освіти, орієнтуючись на індивідуальні особливості, знаходять власні способи суб'єктивації в окремих видах навчально-професійної діяльності й у життєдіяльності в цілому. Особистісно-розвивальний підхід передбачає опору на природний процес саморозвитку, самореалізацію, самоствердження особистості [6, с. 77]. У практиці підготовки майбутнього тракториста-машиніста ця методологія передбачає організацію навчання 3 урахуванням його індивідуальних особливостей, надає можливість майбутньому кваліфікованому робітнику ґрунтовно опанувати технології та методики розвитку власного творчого потенціалу.

Конструювання моделі фрормування профресійної компетентності майбутніх трактористів-машиністів здійснювалося на основі ідей вищезазначених підходів, а також сучасного бачення структури професійної освіти. На їх базі були сорормульовані принципи розробки концепції.

Принцип об'єктивності є основним вихідним положенням будь-якого дослідження. Він передбачає комплексне врахування фракторів, які породжують те чи інше явище, умов, за яких таке явище розвивається, адекватності підходів і засобів, які дають можливість одержати справжнє знання.

3 цього приводу С. Гончаренко слушно вказує [1, с. 91]: під час вивчення особистості й груп людей об'єктивність способів впливу на них стає наріжним каменем сучасної педагогічної науки. Не зайве додати, що принцип об'єктивності передбачає вимогу доказовості наукових фрактів, яка своєю чергою породжує умову альтернативності розв'язання проблеми. Йдеться про те, що, наприклад, обґрунтовані нами умови, етапи, методи, форми, засоби фрормування професійної компетентності майбутнього інженера-механіка мають бути розглянуті з позиції альтернативності; варто проаналізувати можливість існування інших логічних варіантів, зокрема прихованих, неочевидних.

Принцип всебічності як методологічний принцип $€$ визначальним в отриманні якісних, певних результатів наукового пошуку. Варто погодитися з ученими в тому, що будь-який процес чи явище пов'язані з іншими явищами й процесами, а тому його ізольований розгляд неминуче призведе до спотвореного, помилкового висновку [7]. Таким чином, згідно з вимогами принципу всебічності, профресійну компетентність студента маємо вивчати як педагогічне явище, що відносно відокремлене від зовнішніх умов, але водночас перебуває в тісному зв'язку з освітнім середовищем аграрного вищого навчального закладу. Додамо, що саме це наукове положення і визначає можливість моделювання досліджуваного процесу, комплексно вивчати френомен у стані його розвитку.

Принцип єдності історичного й логічного вимагає в кожному науковому дослідженні поєднувати вивчення історії об'єкта (генетичний аспект) і теорії, а також перспектив його розвитку [1; 3; 6].

Провідною вимогою вказаного принципу $\epsilon$ наступність, урахування минулих наукових надбань. Справедливо, на нашу думку, вказує В. Загвязінський, що нове, яке не враховує нагромадженого досвіду, традицій, наукових досягнень 
минувшини, виявляється дуже нежиттєздатним, «перевдягнутим» старим [3].

Принцип системності враховує багатогранність сторін, різноманітність внутрішніх і зовнішніх факторів впливу на досліджуваний об'єкт, передбачає його розгляд як системи.

Принцип партнерства й співробітництва орієнтує на цілеспрямоване забезпечення міжособистісної навчальної взаємодії в системі «педагог - учень»; встановлення суб'єкт-суб'єктних взаємин у системі «учень - учень», діалогізацію процесу навчання шляхом творчого застосування суб'єктно-діяльнісних методів, методик і технологій профресійної підготовки [8, с. 34-35].

Крім наголошених, у нашому дослідженні враховувалися принципи єдності зовнішніх впливів і внутрішніх умов, цілісності, активної діяльності особистості, поєднання сущого й належного, детермінізму, концептуальної єдності дослідження, структурності, самоорганізації, сутнісного аналізу, вимоги до реалізації яких детально виписано в науковій літературі.

До педагогічних принципів як керівних ідей, нормативних вимог і рекомендацій, що надають можливість науково-педагогічним працівникам професійно-технічного навчального закладу цілеспрямовано, логічно, послідовно й системно формувати професійну компетентність майбутніх трактористів-машиністів, віднесено: основні педагогічні принципи - розвивального й виховального навчання, професійної мобільності, фрундаментальності освіти, модульності, професійної спрямованості, інформатизації (комп'ютеризації) навчання; часткові педагогічні принципи - безперервності; прямого й зворотного зв'язку з виробництвом; створення інформаційно-освітнього середовища; моделювання технічної діяльності; економічної доцільності.

Указані принципи разом із загальнопедагогічними (науковості навчання; зв'язку навчання 3 життям; систематичності й послідовності в навчанні; доступності навчання; наочності навчання; міцності, усвідомленості й дієвості результатів навчання, виховання та розвитку тощо) спрямовані на реалізацію концептуальних ідей цілеспрямованого формування професійної компетентності майбутніх трактористів-машиністів сільськогосподарського виробництва.

Висновки. Визначені методологічні підходи (системний, компетентнісний, діяльнісний та особистісно-розвивальний) дають змогу схарактеризувати формування професійної компетентності майбутніх трактористів-машиністів як керований процес у межах закладу освіти. Ураховуючи складність системи методологічних підходів, можна стверджувати, що кожен із них може бути реалізованим повною мірою тільки в їх сукупності.

Зазначені принципи (об'єктивності; всебічності; єдності історичного й логічного; системності; партнерства й співробітництва; розвивального й виховального навчання; професійної мобільності; фрундаментальності освіти; модульності; профресійної спрямованості; інорорматизації (комп'ютеризації) навчання; безперервності; прямого й зворотного зв'язку з виробництвом; створення інформаційноосвітнього середовища; моделювання технічної діяльності; економічної доцільності) спрямовані на реалізацію концептуальних ідей цілеспрямованого фрормування професійної компетентності майбутніх трактористів-машиністів сільськогосподарського виробництва.

Наукове дослідження не вичерпує всіх аспектів проблеми фрормування профресійної компетентності майбутніх трактористів-машиністів і підтверджує необхідність її подальшої розробки. Оскільки системне моделювання передбачало не лише проєктування, але й визначення шляхів упровадження пропонованої методики фрормування профресійної компетентності майбутніх трактористів-машиністів, перспективи подальших наукових розвідок вбачаємо в розробці методичних особливостей реалізації методики.

\section{БІБЛІОГРАФІЧНИЙ СПИСОК:}

1. Гончаренко С.У. Педагогічні дослідження. Методологічні поради молодим науковцям. Київ-Вінниця : ТОВ «Планер», 2010. 308 с.

2. Енциклопедія освіти / гол. ред. В.Г. Кремень. Київ : Юрінком Інтер, 2008. 1040 с.

3. Загвязинский В.И., Атаханов В. Методология и методы психолого-педагогического исследования: учебное пособие. Москва : Издательский центр «Академия», 2007. 208 с.

4. Просресійна педагогічна освіта: компетентнісний підхід : монограсрія / О.А. Дубасенюк та ін. ; за ред. О.А. Дубасенюк ; Житомир. держ. ун-т ім. І. Франка. Житомир : ЖДУ ім. І. Франка, 2011. 412 с.

5. Философский энциклопедический словарь / Гл. ред.: Л.Ф. Ильичев, П.Н. Федосеев, С.М. Ковалев, В.Г. Панов. Москва : Сов. энцикл., 1983. 840 с.

6. Фіцула М.М. Педагогіка вищої школи : навчальний посібник. Київ : «Академвидав», 2006. 352 с.

7. Шейко В.М., Кушнаренко Н.М. Організація та методика науково-дослідницької діяльності : підручник. 5-е вид., стер. Київ : Знання, 2006. 307 с.

8. Ягупов В.В. Суб'єктність учнів як основна детермінанта дистанційного навчання в системі професійно-технічної освіти. Наук. вісник Ін-ту проф.тех. освіти НАПН України. Профресійна педагогіка : збірник наукових праць. Вип. 11 / ІПТО НАПН України ; Ред. кол. В.О. Радкевич (голова) та ін. Київ : Міленіум, 2016. С. 29-37. 